\title{
GURU SEBAGAI MODEL DAN TELADAN DALAM MENINGKATKAN MORALITAS SISWA
}

\begin{abstract}
:
Oleh: In the school environment, character of authority, personality, and role model which Kandiri bave been owned by teacher wiil give positive impact to student's personality and Arfandi morality. This is an understanding of right Islamic values, which grow by process of training, habituation or moral guidance by giving the great role model, speech, Email: punishment as well as strict attitude of an Islamic educational teacher. The proper Kandiri93@gmail.com arfandi.1985@gmail.com

Universitas Ibrahimy
\end{abstract}

Keywords: Teacher, Role Model, Student's Morality Enhancement

\section{PENDAHULUAN}

Setiap orang pasti menginginkan kehidupan di masa yang akan datang dengan penuh kebahagiaan. Semua itu bergantung pada putra-putrinya, sehingga setiap orang berkeinginan agar putra-putrinya menjadi orang yang berpendidikan dan bermoralitas. Oleh karena itu perlu adanya pembinaan moral yang khusus dan terarah bagi putra-putrinya sebagai penerus bangsa dan agama, sehingga dapat memenuhi semua harapan yang dicita-citakan.

Berbicara masalah moral, pada era globalisasi khususnya di Indonesia saat ini banyak terjadinya aksi dan tindak kekerasan yang seringkali kita lihat baik melalui media elektronik maupun cetak seperti pemukulan murid kepada guru yang sampai tewas, siswi jual diri untuk mendapatkan sejenis narkotika, tawuran antar pelajar, pemerkosaan, pembunuhan, mabuk-mabukkan, dan tindak anarkis yang lain. Itulah salah satu fenomena mengkhawatirkan dan menyedihkan yang kini tengah menimpa bangsa kita, salah satu penyebabnya adalah karena terjadinya dekadensi moral.

Di tengah zaman di mana dekadensi moral telah terjadi di mana-mana, baik di kalangan anakanak, remaja, maupun orang dewasa, maka penekanan kembali terhadap pembinaan moral merupakan kebutuhan yang sangat penting dan mendesak yang tidak bisa lagi diabaikan. Masa remaja adalah suatu masa di mana seseorang belum mempunyai pendirian yang kuat, terlebih lagi pada saat sekarang di era globalisasi dan era informasi ini banyak remaja yang terpengaruh hal-hal yang negatif. Hal ini perlu dicegah dan dibina karena pada masa remaja merupakan masa pergolakan jiwa setiap manusia.

Zakiyah Darajat dikutip oleh Muhammad Al-Mighfar memberikan pernyataan, "Remaja merupakan masa peralihan dari masa anak-anak menuju masa dewasa." Oleh karena itu, pada masa remaja sangat dibutuhkan perhatian yang ketat dari orang tua dan seorang guru, di samping itu pembinaan moral juga bisa dilakukan dengan cara melakukan suatu kedisiplinan yang sangat, khususnya pada saat berada di sekolah. Hal ini dikarenakan setiap orang tua yang memasukkan anaknya kesekolah berkeinginan mempunyai anak yang berkepribadian baik serta berkeinginan untuk bisa mengharumkan nama orang tua serta keluarga.

Di antara unsur-unsur yang sangat urgen dalam proses kegiatan belajar mengajar adalah

\footnotetext{
${ }^{1}$ Muhammd Al-Mighwar, Psikologi Remaja, (Pustaka setia: Bandung, 2006), 17.
} 
seorang guru. Untuk mengantarkan peserta didik dapat meraih cita-citanya tentu hal ini tidak akan lepas dari paran dan tanggung jawab dari seorang guru untuk memenuhi apa yang menjadi kebutuhan peserta didik baik dari aspek moral, spiritual, intelektual, estetika maupaun kebutuhan yang berbentuk fisik dari peserta didik itu sendiri.

Guru sebagai seorang pendidik harus mampu melihat kondisi psikologi siswa, karena seorang guru memiliki andil yang sangat besar dalam pembentukan moral siswa. Oleh karena itu, keteladanan, kepribadian dan kewibawaan yang dimiliki oleh guru akan memberikan dampak yang positif ataupun dampak yang negatifnya dalam pembentukan kepribadian dan watak anak. Hal ini sesuai dengan firman Allah SW'T yang berbunyi, "Sesunggubnya telah ada pada (diri) Rasulullab $S A W$ itu suri tauladan yang baik bagimu (yaitu) bagi orang yang mengharap (rahmat) Allah SWT dan kedatangan hari kiamat dan Dia banyak menyebut Allah SWT."

Ayat tersebut menjelaskan bahwa Nabi Muhammad SAW adalah suri tauladan, oleh karena itu guru seharusnya memiliki kepribadian yang baik seperti apa yang ada pada diri Nabi Muhammad SAW. Guru dalam kegiatan belajar mengajar adalah orang yang uatam adan pertama yang berinteraksi langsung dengan siswa, oleh karena itu tentu guru harus mampu memberikan uswah hasanah (contoh yang baik) terhadap para siswa. Positif dan negatifnya kepribadian guru akan dapat memberikan dampak secara signifikan terhadap siswa, oleh karena itu dalam kegiatan belajar mengajar guru harus benar-benar memilki kepribadian yang luhur yang bisa dicontoh oleh para siswa karena hal itu akan menjadi barometer tentang keberhasilan siswa dalam negingikuti kegiatan belajar. ${ }^{2}$ Dengan demikian sikap dan kepribadian dari seseorang guru itu akan berdampak secara signifikan, bilamana para siswa mempunyai pandangan yang buruk terhadap kepribadaian guru dan tentu hal ini akan menghampat dalam kegitan belajar mengajar dan akan berdampak terhadap pencapaian prestasi dan hasil belajar siswa nyang kurang maksimal. ${ }^{3}$

\footnotetext{
2 Abdul Rachman Shaleh, Pendidikan Agama dan Pembangunan Watak Bangsa, (Jakarta: PT.Raja Grafindo persada, 2006), 134-135.

${ }^{3}$ Muhibbin Syah, Psikologi Belajar, (Jakarta: Rajawali Pers, 2009), 149.
}

Keberadaan dari seorang guru sebagai pendidik dan tenaga pengajar tentu dituntut untuk mempunyai kompetensi kepribadian dalam kegiatan belajar mengajar, dengan memiliki kompetensi itu, maka seorang guru harus berkepribadian mantap, stabil, dewasa, arif, wibawa, dan disiplin. ${ }^{4}$ Disiplin guru yang dimaksud yaitu disiplin dalam mengajar, memberikan sanksi, kultum serta sikap tegas pada saat peserta didik melakukan sesuatu yang tidak sesuai tata tertib yang ada. Dengan hal tersebut, maka moral siswa akan berubah dan menjadi lebih baik lagi dari pada sebelumnya.

Salah satu mata pelajaran yang memiliki andil yang sangat penting yaitu Pendidikan Agama Islam (PAI) karena mata pelajaran tersebut mengajarkan moral sesuai dengan tuntunan agama Islam yang seutuhnya. Dalam agama akan mengajarkan tentang moral yang baik karena moral yang baik itu yang akan menjadi pijakan tanpa adanya unsur paksaan dari luar mengingat nilai moral itu sendiri terdapat dari keyakinan agama dan kesadran sendiri. ${ }^{5}$

Dalam lingkungan sekolah inilah pemahaman nilai-nilai agama islam yang benar lahir dari proses pelatihan dan pembiasaan atau pembinaan moral dengan memberikan suri tauladan yang baik, kultum, sanksi serta sikap tegas dari seorang guru PAI. Dalam pembinaan moral yang baik tidak didasarkan pada ajaran-ajaran yang sifatnya perintah atau larangan semata. Akan tetapi harus berdasarkan pada pemberian contoh yang baik dari seorang guru yang berada di lingkungan sekolah. Dengan demikian sangat urgen bagi seorang guru untuk memberikan bimbingan secara khusus agar siswa bisa memiliki moralitas yang baik salah satunya adalah dengan melalui pendidikan agama Islam. Hal inilah yang kemudian dijadikan sebuah alasan oleh penulis untuk memformasikan pembahasan pada peran dan tanggung jawab guru PAI dalam peningkatan moral siswa.

\footnotetext{
${ }^{4}$ E. Mulyasa, Menjadi Guru Profesional, (Bandung: Remaja Rosdakarya, 2010), 121-122.

5 Zakiyah Daradjat, Membina Nilai-Nilai Moral di Indonesia, (Jakarta: Bulan Bintang, 1977), 20.
} 


\section{PEMBAHASAN}

\section{Guru Sebagai Model dan Teladan}

\section{Peran Guru}

Arti peran guru merupakan salah satu aktivitas yang harus dikerjakan oleh seorang guru yang menjadi peran dan tanggung jawabnya sebagai guru. ${ }^{6}$ Peran guru yaitu bagaimana guru bisa memberikan pengaruh dan motivasi terhadap para siswanya sehingga para siswa bisa melakukan sesuatu sesuai dengan apa yang diinginkan oleh guru tersebut. Sebagaimana disebutkan oleh Zakiah Daradjat, bahwa seorang guru harus mempunyai kompetensi dan pengalaman dengan tujuan bisa memberikan kemudahan terhadap para siswa di dalam kegiatan belajar mengajar baik berupa motivasi, bimbingan dan arahan. ${ }^{7}$ Adam dan Pecey menyampaikan bahwa peranan penting dari seoarang guru antara lain adalah guru sebagai pengelola kelas (management classroom), sebagai evaluator dan sebagai mediator. ${ }^{8}$

Sebagaimana yang dikemukakan oleh Surya tentang bagaimana peran penting seorang guru dalam masyarkat, keluarga, sekolah. Dalam kegiatan belajar mengajar di sekolah seorang guru memilki beberapa peran penting antara lain adalah guru dalam pengelolaan kegiatan belajar mengajar, guru mendesain dan merancang pembelajaran, guru menilai dan mengevaluasi hasil belajar siswa. Peran guru di dalam lingkungan keluarga, guru berperan sebagai pembimbing, dan sebagai pendidik dalam keluarga. sementara itu peran guru di masyarakat, yaitu seorang guru berperan sebagai pengarah dan pembina.

Rochman Natawijaya menyampaikan bahwa peran guru sangat urgen di dalam kegiatan belajar mengajar di sekolah, peran guru tersebut adalah guru sebagai perancang, pengelola pembimbing, pendidik, pelatih, penilai dan mengevalusasi hasil belajar siswa. ${ }^{9}$ Dengan demikian, bahwa peran seorang

\footnotetext{
${ }^{6}$ Tohirin, Pskologi Pembelajaran Pendidikan Agama Islam, (Jakarta: PT. Grafindo Persada, 2006), 165.

7 Zakiyah Daradjat, Dkk, Metode Pengajaran Agama Islam, (Jakarta: Bumi Aksara, 1996), 266.

${ }^{8}$ Hawi, Kompetensi Guru PAI (Jakarta: PT.Raja Grafindo, 2014), 45.

9 Sutirna, Bimbingan dan Konseling: Pendidikan Formal, Nonformal, dan Informal, (Yogyakarta : CV Andi Offset, 2013), 59-60.
}

guru sangat erat sekali hubungannya dengan aktivitas dan pekerjaan dari seorang guru itu sendiri, tentu dalam kegiatan belajar mengajar guru harus sesuai dengan peran dan tanggung jawabnya. Tugas dan peran guru tidak hanya sebagai pengajar dan pendidik saja, melainkan juga yang tidak kalah penting juga berhadapan dengan seperangkat komponen yang terkait dengan pengembangan potensi anak didik.

E. Mulyasa menyebutkan bahwa ada bebrapa peran penting sebagai guru PAI dalam kegiatan belajar mengajar, antara lain adalah sebagai berikut: ${ }^{10}$

a. Guru sebagai pendidik: guru yang kapasitasnya sebagai seorang pendidik, yang menjadi publik figur, teladan dan panutan bagi para peserta didik, dan juga bagi lingkungan di mana guru berada. Dengan demikian, guru harus mempunyai kompetensi pedagogik, kepribadian, sosial dan profesional selain memiliki kompetensi tersebut guru juga harus mempunyai ukuran kualitas pribadi, di antara kualitas pribadi itu antara lain adalah mencakup kemandirian guru, kedisiplinan guru, tanggung jawab guru, dan berwibawa. Termasuk dari tanggung jawab guru adalahguru harus bisa memahami dan mengetahui tentang nilai-nilai, moralitas, norma dan aturan, serta berkomitmen untuk berperilaku dan berbuat sesuai dengan nilai dan norma tersebut. Selain itu seorang guru juga harus bertanggung jawab terhadap segala tindakannya dalam kegiatan belajar mengajar di sekolah, dan dalam kehidupan bermasyarakat. Termasuk dari kewibawaan guru ialah guru harus mempunyai kecerdasan baik kecerdasan intelektual, spiritual dan emosional serta memiliki moralitas, selain itu juga guru harus memiliki kemampuan di dalam memahami teknologi, sains dan seni sesuai dengan bidang keilmuan yang dikembangkan. Secara mandiri seorang guru harus bisa memberikan keputusan sesuai dengan apa yang berlaku, yang lebih prioritas terkait maslah kegiatan belajar mengajar, dan bertindak sesuai dengan sitausi dan kondisi dari peserta didik. Termasuk guru yan memiliki kedisiplinan adalah setiap akativitas guru harus menyesuaikan dengan tata tertib, norma, dan nilai-nilai secara komprehensif dan

\footnotetext{
${ }^{10}$ E. Mulyasa, Menjadi Guru Profesional, (Bandung: Remaja Rosdakarya, 2010), 37.
} 
secara konsisten. Atas dasar kesadaran secara profesional itu, maka guru bertugas untuk tetap konsisten mendisiplinkan para peserta didik di sekolah, lebih-lebih ketika kegiatan belajar mengajar sedang berlangsung. Dengan demikian, seorang guru di dalam menjaga kedisplinan para peserta didik harus dimulai dari guru itu sendiri, karena dengan keteladanan dan kedisiplinan yang dimiliki guru akan menjadi teladan bagi peserta didik sehingga peserta didik dalam kegiatan belajar mengajar akan mencapai sesuai dengan kompetensi yang diharapkan.

b. Guru sebagai model dan teladan: keberadaan guru dalam kegiatan belajar mengajar merupakan salah satu figur yang akan menjadi teladan untuk semua peserta didik dan juga akan menjadi teladan bagi semua elemen masyarakat yang berinteraksi dengannya. Oleh karena itu, apapun yang ada pada diri guru akan tercermin melalui kerendahan diri, tindakan dan kepribadiannya. Guru yang menjadi model dan teladan adalah merupakan salah satu sifat dasar yang harus menjadi prinsip dalam kegiatan belajar mengajar, ketika seorang guru sudah tidak memperhatikan perannya sebagai teladan bagi peserta didiknya maka hal ini akan mengurangi keseriusan dan keefektifan peserta didik dalam kegiatan belajar mengajar. Tidak perlu menjadi beban dan tanggungjawab yang berat bagi guru di dalam memahami peran dan fungsinya, dengan kerendahan, keterampilan dan keletaladanannya akan membuat kegiatan belajar mengajar semakin kondusif dan dan meningkatnya hasil belajar peserta didik.

Kepribadian dan keteladanan dari seorang guru tentu akan menjadi tantangan tersendiri bagi guru, mengingat segala aktivitas apapun yang menyangkut guru akan menjadi sorotan bagi peserta didik bahkan juga masyarakat sekitarnya di mana guru itu berada. Ada beberapa hal yang harus menjadi perhatian bagi guru dalam kegiatan belajar mengajar.

a. Sikap dasar: sikap dasar ini merupakan salah satu yang menyangkut dengan postur psikologis yang akan nampak jelas tentang permasalahan yang penting, seperti kegagalan, kebenaran, dan keberhasilan. b. Bicara dan gaya bicara: guru dalam menggunakan bahasa dalam berkomunikasi kerena hal itu merupakan alat dalam berfikir dan bersikap.

c. Pakaian: merupakan perlengkapan pribadi yang amat penting dan menampakkan ekspresi seluruh kepribadian.

d. Hubungan kemanusiaan: sikap guru dalam berinterkasi harus dilakukan dengan hubungan yang baik, beretika, bermoral.

e. Proses berfikir: guru dalam memecahkan sebuah permasahan harus melalui proses berfikir yang komprehensif dan integratif.

Apa yang menjadi perhatian guru yang harus dilakukan sesuai dengan apa yang diterapkan di atas itu sebagai gambaran. Oleh karena itu seorang guru bisa menambahkan hala-hal terpenting yang ada relevansinya dengan tingkah laku lain yang sering terjadi dalam kehidupan bersama para peserta didik di lingkungan sekolah. Hal ini memberikan penegasan tergadap guru pentingnyan bisa memberikan keteladanan bagi peserta didik dalam melakukan aktivitasnya dalam kegiatan belajar mengajar.

Bila dilihat secara teoritis, keteladanan yang dimiliki oleh seorang guru merupakan salah satu bagian integral yang tidak bisa dipisahkan satu sama lain dengan apa yang ada pada diri guru, oleh karena itu tanggung jawab apapun yang ada hubungannya dengan teladan maka harus diterima oleh guru. Apa pun yang menjadi profesi dari setiap orang baik profesi sebagai guru, profesi sebagai dokter dan lainnya akan memiliki tuntutan tuntutan khusus, oleh karena itu apaun yang berkenaan dengan tanggungjwabnya sebagai profesi harus dilakukan dengan baik dan tidak boleh menolaknya. Ada sebuah pertanyaan yang harus diberikan kepada guru tentang sebuah keteladanan apakah seorang guru wajib menjadi tauladan yang baik hanya ketika dalam kegiatan belajar mengajar saja atau dalam segalah aktivitas dalam kehidupan sehari- harinya?

Dengan pertanyaan seperti itu tentu profesi, peran serta tanggungjawab sebagai guru teladan bisa dilakukan bukan hanya dalam kegiatan belajar mengajar di kelas saja, akan tetapi juga dalam lingkungan dimana guru itu berada. Dengan demikain bukan buakan berarti guru tidak memiliki kebebasan 
sama sekali. Dalam batas-batas tertentu, sebagai manusia biasa tentu saja guru memiliki berbagai kelemahan, dan kekurangan.

\section{Peran dan Tanggung jawab Guru}

Peran dan tanggung jawab guru sebagai publik figur dan tenaga fungsional dengan kapasitas yang utama adalah pendidik dan pengajar di jalur pendidikan formal baik jenjang Taman Kanak-Kanak (TK), Sekolah Dasar (SD), Sekolah Menengah Pertama (SMP), Sekolah Menengah Atas/Kejuruan (SMA, SMK). ${ }^{11}$ Menurut Undang-Undang Republik Indonesia Nomor 14 Tahun 2005 Tentang Guru dan Dosen, Pasal 1 Ayat 1 menjelaskan bahwa guru adalah pendidik profesional dengan tugas utama mendidik, mengajar, membimbing, mengarahkan, melatih, dan mengevaluasi peserta didik pada pendidikan anak usia dini jalur pendidikan formal, pendidikan dasar, dan pendidikan menengah. Selain itu dalam Peraturan Pemerintah RI No. 74 Tahun 2008 tentang guru pasal 1 yang memaparkan tentang tujuh tugas utama seorang guru/pendidik yaitu mendidik, mengajar, membimbing, mengarahkan, melatih, menilai, dan mengevaluasi mengevaluasi peserta didik pada pendidikan anak usia dini jalur pendidikan formal, pendidikan dasar, dan pendidikan menengah. ${ }^{12}$

Guru Pendidikan Agama Islam memiliki beberapa peran dan tanggungjwab di dalam membentuk moralitas peserta didik antara lain adalah sebagai berikut:

a. Seorang guru agar bisa memberikan motivasi terhadap peserta didik agar giat di dalam mengikuti kegitan belajar mengajar.

b. Guru ikut serta berpartisipasi di dalam penyusunan kurikulum di sekolah.

c. Guru memberikan penyuluhan dan pembinaan bagi peserta didik yang meliputi; mental, watak, keperibadia, dan jasmani dan rohani.

d. Guru agar bisa mengidentifikasi tentang hal-hal yang berkaitan dengan peserta didik, baik dalam kesulitan belajar dan mencarikan alternatifnya

\footnotetext{
${ }^{11}$ Keputusan Menteri Negara Pendayagunaan Aparatur Negara No. 84 Tahun 1993, Tentang Jabatan Guru dan Angka Kreditnya, Bab. II Pasal 2.

${ }^{12}$ Peraturan Pemerintah RI no. 74 tahun 2008 Tentang "Guru”, Bab. I, Ayat 1.
}

setelah itu di evaluasi tentang keberhasilan dan kemajuan dalam hasil belajar.

e. Guru harus mengadakan penelitian tentang fenomina yang ditemukan di kelas tentang kegiatan belajar di sekolah.

f. Guru ikut berpartisipasi di masyarakat dan banyak melakukan silaturrahim dan juga turut serta di dalam menjaga keamanan dan ketertiban di masyarakat.

g. Guru yang notabenannya sebagai pendidik harus bisa mengamalkan dan menghayati nilai-nilai yang terkandung di dalam pancasila

h. Guru ikut serta dalam stabilitas dan kondusifitas Negara republic Indonesia agar terciptanya kedamaian dan persatuan.

i. Guru ikut serta dalam terciptanya dan kesuksesan pembangunan baik SDM maupun SDA.

j. Guru ikut bertanggungjawab dalam meningkatkan kualitas dan profesionalitas guru. ${ }^{13}$

Di samping itu, proses pembudayaan nilainilai luhur perlu didukung oleh komitmen dan kebijakan pemangku kepentingan serta pihak-pihak terkait lainnya, termasuk dukungan sarana dan prasarana yang diperlukan. ${ }^{14}$

\section{Peningkatan Moralitas Siswa}

Arti kata moral diambil dari bahasa Latin, mores yang mempunyai arti adat kebiasaan. Sedangkan kata mores ini memiliki kesamaan arti (sinonim) dengan kata mos, moris manner mores atau manners, morals. Kata moral di dalam bahasa Indonesia memiliki arti akhlak atau kesusilaan yang mengandung makna tata tertib atau batin atau tata tertib hati nurani yang menjadi pembimbing tingkah laku batin dalam hidup. ${ }^{15}$

Pengertian moral atau akhlak menurut pendapat Imam Al-Ghazali, yaitu kemantapan jiwa

\footnotetext{
${ }^{13}$ Moh.Uzer Usman, Menjadi Guru Profesional, Jakarta: Rosdakarya, 2001), 6.

${ }^{14}$ Asmuki dan Wilda Al Aluf, "Pendidikan Karakter di Pesantren", Edupedia: Jurnal Studi Pendidikan dan Pedagogi Islam, Vol. 2, No. 2, (Januari 2018), 2.

${ }^{15}$ Mansur Muslich, Pendidikan Karakter Menjawab Tantangan Krisis Multidemensional (Jakarta: Bumi Aksara, 2011), 20.
} 
yang bisa melahirkan tindakan dengan mudah tanpa membutuhkan pemikiran dan perenungan. Jika setiap tingkah laku yang lahir dari keadaan jiwa tersebut adalah baik menurut ukuran akal dan agama, maka keadaan tersebut dinamakan akhlak atau moral yang baik. Bila tingkah laku yang dihasilkan adalah buruk, maka keadaan sumbernya disebut akhlak atau moral yang buruk.

Sedangkan kesadaran moral merupakan salah satu komponen penting untuk bisa menjadikan perilaku dan tindakan manusia selalu bermoral, berperilaku susila tentu hal ini akan membuat tindakannya akan sesuai dengan norma yang berlaku. Atas kesadaran moral tersebut akan didasarkan atas nilai-nilai yang benar-benar secara esensial dan fundamental. Perilaku manusia yang berdasarkan atas kesadaran moral, maka perilaku dan tindakannya akan selalu dilakukan sebagaimana yang seharusnya, kapan saja dan di mana saja.

Bagi orang yang memiliki kesadaran moral meskipun tanpa diawasi dan tidak ada orang yang melihatnya, maka setiap tindakan yang bermoral akan selalu dilakukan dimana pun dan kapan pun. Sebab apa yang menjadi perilaku dan tindakannya didasarkan atas kesadaran, bukan berdasar pada hawa nafsu dan suatu kekuasaan apapun dan juga bukan karena dipaksakan, melainkan didasarkan atas "kekuasaan" kesadaran moral itu sendiri.

Menurut Van Magnis ada tiga komponenpenting tentang kesadaran moral antara lain adalah sebagai berikut:

a. Memiliki perasaan wajib atau keharusan untuk melakukan tindakan yang bermoral, hal itu akan terjadi di dalam setiap hati nurani dan hati sanubari manusia, terhadap siapapun, berada ditempat dimanapun, dan kapanpun. Bila diperhatikan maka akan terlihat jika kewajiban tersebut tidak dapat dirubah dan ditawar-tawar, karena hal itu sebagai bentuk kewajiban maka andai kata dalam pelaksanaan tidak dipatuhi berarti suatu pelanggaran moral.

b. Rasional, kesadaran moral dapat dikatakan rasional, karena berlaku umum dan terbuka bagi pembenaran atau penyangkalan. Dalam masalah rasionalitas kesadaran moral, manusia meyakini bahwa akan sampai pada pendapat yang sama sebagai suatu masalah moral, asal manusia bebas dari paksaan dan tekanan, tidak mencari keuntungan sendiri, tidak berpihak, bersedia untuk bertindak sesuai dengan kaidah yang berlaku secara umum.

c. Kebebasan, atas kesadaran moralnya seseorang bebas untuk mentaatinya, bebas dalam menentukan perilakunya dan didalam penentuan itu sekaligus terpampang pula nilai manusia itu sendiri. ${ }^{16}$

Terdapat beberapa faktor yang bisa berpengaruh terhadap moral remaja (peserta didik) ketika yang bersangkutan menginjak dewasa. Hal ini penting diperhatikan dalam upaya meningkatkan moral siswa. Berikut ini ada beberapa faktor yang dapat menurunkan moral dikalangan para remaja :

a. Kurangnya perhatian dan pendidikan agama oleh keluarga: keberadaan orang tua di dalam lingkungan keluarga adalah merupakan salah satu publik figur atau tokoh percontohan oleh anak-anak bahkan di dalam setiap kehidupan dan aktivitas sehari-hari, termasuk di dalam aspek kehidupan sehari-hari tetapi di dalam soal pendidikan keagamaan hal itu seakan-akan terabaikan. Sehingga akan lahir generasi baru yang bertindak tidak sesuai ajaran agama dan bersikap materialistik.

b. Pengaruh lingkungan yang tidak baik: lingkungan merupakan salah satu faktor yang dapat mempengaruhi para remaja baik yang tinggal di desa maupun yang tinggal di kota besar yang menjalankan kehidupan yang individualistik dan materialistik. Sehingga dengan demikian ketika mengejar keduniaan dan kemewahan tersebut mereka sanggup melakukan apa saja yang sesuai dengan keinginannya tanpa terlebih dahulu menghiraukan hal itu bertentangan dengan agama atau tidak, baik atau buruk.

Tekanan psikologi yang dialami remaja: tekanan yang terjadi terhadap para remaja akan mengalami tekanan dan gangguan psikologis ketika keberadaan di dalam rumah diakibatkan oleh adanya perceraian atau pertengkaran orang tua

\footnotetext{
${ }^{16}$ Ach. Charris Zubair, Kuliah Etika, (Jakarta : Rajawali Pers, 1995), 51.
} 
yang menyebabkan si anak tidak betah di rumah dan menyebabkan dia mencari pelampiasan.

Gagal dalam studi/pendidikan: remaja yang gagal dalam pendidikan atau tidak mendapat pendidikan, mempunyai waktu senggang yang banyak, jika waktu itu tidak dimanfaatkan sebaik-baiknya, bisa menjadi hal yang buruk ketika dia berkenalan dengan hal-hal yang tidak baik untuk mengisi kekosongan waktunya.

Peranan media massa: eksistensi media massa akan membuat para kelompok atau golongan yang mudah dipengaruhi, karena remaja sedang mencari identitas diri sehingga mereka dengan mudah untuk meniru atau mencontoh apa yang dia lihat, seperti pada film atau berita yang sifatnya kekerasan, dan sebagainya.

Perkembangan teknologi modern: adanya perkembangan teknologi modern saat ini seperti mengakses informasi dengan cepat, mudah dan tanpa batas juga memudahkan remaja untuk mendapatkan hiburan yang tidak sesuai dengan mereka.

\section{Pembinaan Moral dan Agama Bagi Generasi Muda}

Kehidupan moral tidak dapat di pisahkan dari keyakinan beragama. Karena nilai-nilai moral yang tegas, pasti akan tetap, tidak berubah karena keadaan, tempat dan waktu adalah nilai yang bersumber pada Agama. Karena itu dalam pembinaan generasi muda, perlulah kehidupan moral dan agama itu sejalan dan mendapat perhatian yang serius.

Dalam pembinaan generasi muda itu, peranan wanita sangat penting karena pembinaan itu berarti pembinaan segala aspek dari kehidupan mereka, terutama pembinaan pribadi yang dimulai sejak si anak lahir, bahkan sejak dalam kandungan. Di samping itu perlu kita sadari bahwa pembinaan pribadi dan moral itu terjadi melalui semua segi pengalaman hidup, baik melalui penglihatan, pendengaran dan pengalaman yang dilalui. Maka semakin kecil umur sianak semakin banyak ia bergaul dengan ibunya dan semakin banyaklah ia menyerap pengalaman yang akan ikut membina pribadinya dari ibunya sendiri. Karena itu peranan wanita sangat penting dalam pembinaan generasi muda.
Kaburnya nilai-nilai di mata generasi muda adalah masalah pokok yang sangat menonjol saat ini. Mereka di hadapkan kepada berbagai kontradiksi dan aneka ragam pengalaman moral, yang menyebabkan mereka bingung untuk memilih mana yang baik untuk mereka. Hal ini nampak jelas pada mereka yang sedang berada pada usia remaja, terutama pada mereka yang hidup di kota-kota besar Indonesia, yang mencoba mengembangkan diri ke arah kehidupan yang disangka maju dan modern, dimana berkecamuk aneka ragam kebudayaan asing yang masuk seolaholah tanpa disaring. Berikut cara menghadapi masalah tersebut:

a. Kebudayaan yang asing yang masuk perlu untuk difilter disaring secara selektif dengan tujuan kebudayaan yang negative bisa diantisipasi penyebarannya.

b. Secara intensif pendidikan agama Islam agar dilakukan secara maksimal, baik dalam lingkungan keluarga, lingkungan sekolah maupun dalam lingkungan masyarakat, dengan demikian kehidupan beragama tersebut akan dapat terjamin dengan baik dan selanjutnya nilai-nilai moral yang baik itu akan dapat menjadi bagian dari pribadi bangsa kita.

c. Perlu dilakukan pendidikan secara khusus bagi orang yang dewasa dalam bidang kesehatan jiwa, supaya mereka dapat menghindari terjadinya goncangan jiwa sehingga tercipta ketenangan dan kebahagiaan dalam kehidupan dirumah dan di masyarakat.

d. Perlu adanya biro-biro konsultasi, untuk membantu orang-orang yang memerlukannya, baik untuk anak dan remaja, maupun untuk orang dewasa.

e. Dalam kegiatan pembinaan itu sebaiknya pemerintah dengan wewenang yang ada padanya mengambil tindakan ataupun keputusan dan langkah-langkah yang tegas dengan mengikutsertakan semua lembaga, para ulama dan pimpinan masyarakat. ${ }^{17}$

\footnotetext{
${ }^{17}$ Zakiah Daradjat, Ilmu Jiwa Agama, (Jakarta : Bulan Bintang, 1991), 131.
} 


\section{KESIMPULAN}

Dalam lingkungan sekolah kewibawaan, kepribadian dan keteladanan yang dimiliki oleh guru akan memberikan dampak yang positif terhapap kepribadian dan moralitas siswa, inilah pemahaman nilai-nilai agama islam yang benar lahir dari proses pelatihan dan pembiasaan atau pembinaan moral dengan memberikan suri tauladan yang baik, kultum, sanksi serta sikap tegas dari seorang guru PAI. Dalam pembinaan moral yang baik tidak didasarkan pada ajaran-ajaran yang sifatnya perintah atau larangan semata. Akan tetapi harus berdasarkan pada pemberian contoh yang baik dari seorang guru yang berada di lingkungan sekolah. Oleh karena itu peran dan tanggungjawab guru dalam meningkatkan moralitas siswa adalah (1) Guru yang memiliki kapasitas sebagai pendidik akan menjadikan dirinya sebagai teladan, panutan dan identifikasi bagi para peserta didik dan lingkungannya. Dengan demikian, ada standar kualitas pribadi tertentu yang harus dimiliki oleh guru yang di dalamnya mencakup kewibawaan, kedisiplinan, kemandirian, dan tanggungjawab. Berkaitan dengan tanggung jawab; guru harus mengetahui, serta memahami nilai, norma moral, dan sosial, serta berusaha berperilaku dan berbuat sesuai dengan nilai dan norma tersebut. (2) Peran guru sebagai model dan teladan yaitu guru merupakan model atau teladan bagi peserta didik dan semua orang yang menganggap dia seperti guru. Sebagai teladan, tentu saja pribadi dan apa yang dilakukan guru akan mendapat sorotan peserta didik serta orang disekitar lingkungannya yang menganggap atau mengakuinya sebagai guru.

\section{DAFTAR RUJUKAN}

Al-Mighwar, Muhammd. Psikologi Remaja. Pustaka setia: Bandung, 2006.

Asmuki dan Wilda Al Aluf, "Pendidikan Karakter di Pesantren”, Edupedia: Jurnal Studi Pendidikan dan Pedagogi Islam, Vol. 2, No. 2, (Januari 2018).

Daradjat, Zakiyah. Membina Nilai-Nilai Moral di Indonesia. Jakarta: Bulan Bintang, 1977.

. Ilmu Jiwa Agama. Jakarta : Bulan

Bintang, 1991.

Metode Pengajaran Agama Islam.
Jakarta: Bumi Aksara, 1996.

Hawi. Kompetensi Guru PAI. Jakarta: PT.Raja Grafindo, 2014.

Mulyasa, E. Menjadi Guru Profesional. Bandung: Remaja Rosdakarya, 2010.

Muslich, Mansur. Pendidikan Karakter Menjawab Tantangan Krisis Multidemensional. Jakarta: Bumi Aksara, 2011.

Shaleh, Abdul Rachman. Pendidikan Agama dan Pembangunan Watak Bangsa. Jakarta: PT.Raja Grafindo persada, 2006.

Sutirna. Bimbingan dan Konseling: Pendidikan Formal, Nonformal, dan Informal. Yogyakarta : CV Andi Offset, 2013.

Syah, Muhibbin. Psikologi Belajar. Jakarta: Rajawali Pers, 2009.

Tohirin. Pskologi Pembelajaran Pendidikan Agama Islam. Jakarta: PT. Grafindo Persada, 2006.

Usman, Moh.Uzer. Menjadi Guru Profesional. Jakarta: Rosdakarya, 2001.

Zubair, Ach. Charris Kuliah Etika. Jakarta : Rajawali Pers, 1995. 